\title{
Work motivation as a determinant of organisational and professional commitment in temporary organisations: theoretical lenses and propositions
}

Ravikiran Dwivedula, Emirates College for Management and Information Technology, Dubai, UAE Christophe Bredillet, Queensland University of Technology, Australia

Ralf Müller, BI Norwegian Business School, Norway

\begin{abstract}
The purpose of this paper is to present a theoretical framework to investigate the relationship between work motivation, organisational commitment and professional commitment in temporary organisations. Through a review of theory, we contend that work motivation has two major patterns - internal motivation (which includes intrinsic, need-based and self-deterministic theories), and external motivation (which includes cognitive or process-based theories of motivation) through which it has been investigated. We also hold the nature of employee commitment to be of three types - affective, continuance and normative. This commitment may be towards either the organisation or the profession. A literature review revealed that the characteristics of the temporary organisation - specifically tenure and task - regulate the relationship between work motivation, organisational commitment and professional commitment. Testable propositions are presented.
\end{abstract}

Keywords: Work motivation, organisational commitment, professional commitment, temporary organisation, project management

\section{Introduction}

Organisational researchers and practitioners have always been interested in work motivation and employee commitment (Meyer, Becker \& Vandenberghe 2004). This is because these variables have considerable influence on both task and behavioral outcomes (Vandenberghe \& Tremblay 2008; Karin \& Birgit 2007). While early work in these areas focused on developing the theoretical bases, and thereby developing the constructs for these variables (Johnson, Chang, \& Yang, 2010), more recent research has established that employees may identify with multiple target groups at the work place. For example, employees may identify with superiors, work groups or occupational (professional) groups at the same time (Haslam, Eggins \& Reynolds 2003). To date, these streams of research have been well investigated in organisational behavior literature. However, they have not been rigorously researched in temporary organisations such as projects and in the project management discipline.

Furthermore, there is rich literature available on how an individual's organisational commitment (OC) relates to his or her professional commitment (PC) (Finley, Mueller \& Gurney 2003; Corley \& Mauksch 1993; Wallace 1993) and work characteristics as antecedent to OC and PC (Mathieu \& Hamel, 1989) from the general management literature. However, this research problem has only been investigated to a limited extent in temporary organisations. For example, there is some research that attempts to understand antecedents to OC such as leadership style (Limsila \& Ogunlana 2007), project communication (Ahimbisibwe \& Nangoli 2012); and on the relation between OC and PC (Wang \& Armstrong 2004). Limited research has been done to 
understand the role of work motivation as a determinant of OC and PC in temporary organisations.

Thus, we have identified three major research gaps:

- First, research on work motivation in projects has predominantly focused on the project manager's role in engaging the team members. A non-managerial perspective has not been considered.

- Second, it does not fully capture the theoretical foundations of employee motivation. This is especially important to not only identify the appropriate constructs (of motivation) but also to investigate their nature of influence over the outcomes such as employee commitment.

- Finally, motivation research in this area assumes a direct relationship between project workers' motives and commitment. The regulating role of the individual's disposition or work context is not considered.

\section{Pre-paradigmatic state of project research}

There have been numerous efforts to propose a unifying theory for project research (Andersen 2006; Leybourne 2007). A relatively young subfield of management, project management research has been characterised by normative research (Cicmil \& Hodgson, 2006). Therefore there has been a call to reexamine how current project management theories and methods are extended to lead to fertile future research ideas. Bredillet (2010) aptly calls this status of project management research as 'pre-paradigmatic', where is there is a conscious effort to replace the old beliefs, values and techniques (see Kuhn, 1970 for a definition of paradigm). Probably as the first step to address this state of research, schools of project management thinking with underlying theory drawn from other subfields of management have been presented (Anbari 1985; Söderlund 2002; Bredillet 2004; Turner, Huemann, Anbari \& Bredillet 2010, as cited in Dwivedula, Bredillet \& Müller 2012). These studies have either attempted to clarify the existing theory (by reconciling existing contradictions), with a focus on under-researched topics, or by bringing in more organisation to an apparently diffused state of research (Sandberg, \& Alvesson 2011).

In this paper, we draw on this line of thinking when we attempt to research the influence of work motivation on the OC and PC of project workers. We attempt to structure the diffused state of work motivation and commitment literature in project management by drawing from the theoretical lenses in organisational behavior literature. Our review of the literature (on work motivation and commitment) support the propositions that centre on these theoretical lenses drawn from organisational behavior. Thus, while bringing in more structure to the theory, we are also cross fertilising ideas from two subfields of management - organisational behavior and project management, even if only in a limited way.

The overarching aim of the current research study is to understand how the different bases of employee motivation affect an employee's commitment towards the organisation and the profession. Specifically, we list the following two research questions for investigation:

1. Is there a difference in the predictive nature of work motivation on OC and PC in temporary organisations (as opposed to permanent organisations)? 
2. What are the regulating variables specific to temporary organisations that affect the relationship between work motivation, OC and PC?

\section{Organisation of the paper}

We have organised this paper along five major sections. In the first section, we will briefly revisit the concepts of temporary organisation, and understand how it is different from a permanent organisation. Although these differences have been well presented by Lundin and Söderholm (1995), this discussion is important to put the propositions in perspective. In the second section, we will briefly discuss the theory on employee commitment (OC \& PC) and work motivation. Through this section, we will present the operational definitions of our variables - work motivation, OC and PC. In the third section, we will present a literature review leading to the propositions of this study. In the fourth section, we will highlight the research gaps identified through our review of theory and literature. We will also elaborate on our proposed research procedure to investigate the problem. This will be followed by the final section, in which we will present our conclusions.

Our unit of analysis is the relationship between work motivation, OC and PC, where the characteristics of the temporary organisation regulate this relationship between (i) work motivation and OC, and (ii) work motivation and PC. Lundin and Söderholm (1995) have shown that time, task, team and transition are the characteristics that differentiate temporary and permanent organisations. These criteria are explained in detail in the following sections. Further, we also consider that work motivation is multidimensional and there are two major approaches to define it - internal motivation (which includes intrinsic, need-based and self-deterministic theories of motivation), and external motivation (which includes cognitive or process-based theories of motivation; for a detailed explanation, see Kanfer 1992). For OC and PC, we refer to Meyer et al's (1993) viewpoint of three types of commitment - affective, continuance and normative commitment.

\section{Temporary organisation versus permanent organisation}

Temporary organisations are often established in the form of projects, which act as agencies to develop a new product or service, manage the inherent risks thereof and the changes needed to make use of the project's product (Turner \& Müller 2003). From the human resource perspective, there are significant differences between temporary and permanent organisations. Unlike permanent organisations that have a rigid organisational structure, temporary organisations are directed through a network of relationships that exist between various project roles (Powell 1990). Further, temporary organisations rely on short-term employment relationships based on the individual's ability and experience to perform a specific task (DeFillippi \& Arthur 1998). This is in contrast to permanent organisations, where employment is long-term and formal. Such an arrangement becomes necessary in the case of temporary organisations where there is a high degree of task and environmental uncertainty, and firms rely on interpersonal processes rather than formal structures to manage this uncertainty (Beckhy 2006).

Lundin and Söderholm (1995) described the characteristics of temporary organisations along four dimensions - time, task, team and transition. We use these dimensions to differentiate between temporary and permanent organisations. 
From the time perspective, temporary organisations and especially projects seem to subscribe to the notion that time is 'linear' and 'finite'. This is to say that such temporary organisations have a definite beginning and end. This notion is in contrast to the 'arrangement' of time in case of permanent organisations which are assumed to exist for eternity. Further, it is also seen that time is arranged as a 'sequence' of phases. In each of these phases, specific tasks need to be performed. However, this is not to say that only unique tasks are performed in each stage of a project.

Given that temporary organisations such as projects are inherently complex, the nature of the tasks performed will be iterative in nature. Therefore, from the task perspective, temporary organisations will contain tasks that can be related by a bidirectional input-output relationship. These tasks can either be unique (performed only once during the project) or may be repeatable. However, as opposed to permanent organisations, where a broad array of tasks need be performed, temporary organisations are created for the completion of specific tasks.

Team is the third concept that is used to demarcate temporary and permanent organisations. The behavioral effects on the actors working in a team in a temporary organisation will occur at two levels. At the first level, an actor enters the team with his or her own expectations or priorities. These may or may not be aligned to the team's interests, or to those of the other team members. It may also be the case where that there is increased mobility of the team members into and out of the team. At the second level, there is the issue of how is the temporary organisation is positioned within the permanent organisation. Will the temporary organisation complement the other temporary and permanent structures within the parent organisation; or will it have conflicting interests? In the later case, it leads to isolation of the temporary organisation, so much so that the members of the temporary organisation may even develop their own norms.

The final distinction between temporary and permanent organisations is explained through the concept of transition. Transition is probably the raison d'être of the temporary organisation as it is created to effect a change, or develop a desirable perception of change among the actors. Either way, it can be understood as being the equivalent of the goal structure of the permanent organisation. Such a change will have behavioral implications for the actors.

\section{Theory}

Organisational commitment and professional commitment

Commitment is defined as a force that binds an individual to a course of action that is relevant to the individual's aims (Meyer \& Herscovitch 2001). This definition has its roots in the explanation provided by Locke et al (1981), who propose that commitment is the individual's determination to try and attain a goal, irrespective of the goal being assigned, anticipative, or being set by the individual. This notion of commitment suggests that an individual's commitment is not strictly directed by volition. This is further clarified by the two theoretical perspectives exchange theory and social identity theory.

Exchange theory presents commitment as an outcome of the transactions between the organisation and its members. However, the member's perception of the favourableness or unfavourableness of the outcome depends on how much the organisation meets the expectations 
of its member. The obverse of exchange theory is presented through Becker's (1960) side-bet theory, wherein he argues that an individual accrues side-bets or gains when he or she takes up membership in an organisation. These extrinsic gains would be lost once the individual's membership in the organisation is terminated. Thus, individuals invest in organisations by staking side-bets or gains that are important to them. The greater the stake, the more the individual's commitment to the organisation.

On the other hand, social identity theory maintains that individuals classify themselves into various social groups which may include both organisational and professional memberships (Tajfel 1982; Dutton et al 1994). Support for this argument comes from various studies that suggest that commitment takes different forms, and may also be directed towards different foci such as the organisation, occupation or profession, team or union (Becker \& Billings 1993; Becker et al 1996; Meyer \& Allen 1997). For a more recent review of commitment typology, see Somers (2010).

Using these two theories as a point of departure, we will consider two foci of commitment among project workers - OC and PC. We will also use the framework suggested by Meyer et al (1993) for OC and PC in terms of three different forms of commitment - affective, continuance and normative.

Affective organizational commitment refers to the employee's identification with, involvement in, and emotional attachment to the organization out of their volition (Meyer, \& Allen 1997). Thus, project workers are characterized by a desire to follow a particular course of action (Meyer \& Herscovitch 2001).

Continuance Organizational Commitment refers to the employee's awareness of costs associated with leaving the organization (Allen \& Meyer 1990). This is to say that project workers can become committed to a course of action because of perceived cost of failing to do so (Meyer \& Herscovitch 2001).

Normative Organizational Commitment refers to the employee's feeling of obligation to remain with the organization; individuals believe they ought to remain (in the organization).Thus, project workers are driven by a sense of perceived obligation to stay in the organization (Meyer \& Herscovitch 2001).

Affective Professional Commitment is defined as the identification with, involvement in and emotional attachment to the profession. Thus, project workers demonstrating strong affective commitment remain members of project management community because they chose to do so (Meyer et al 1993).

Continuance Professional Commitment is defined as commitment based on the employee's recognition of the costs associated with leaving the profession. Thus, project workers with strong continuance commitment perceive that they have much to lose if they leave this profession (Meyer et al 1993). 
Normative Professional Commitment refers to commitment based on a feeling of obligation towards the profession. The project workers feel that they ought to remain in the project management profession (Meyer et al 1993).

\section{Recent research on the relation between $O C$ and PC in temporary organizations}

Research focusing on the relationship between the three foci of OC and PC is limited in the case of temporary organisations. Wang and Armstrong (2004) suggest that project professionals tend to maintain psychological attachment with both their organisation and profession. These results were supported by Dwivedula and Bredillet (2010), who observed significant correlation between affective OC and PC in project workers.

Gibson and Cohen (2003) suggest moderate positive correlation between normative OC and PC. They posit that there is a dependency between project professionals and organisations. The project professionals have the theoretical knowledge about the project processes, tools or methods. However, in order to apply this theoretical knowledge to their projects, they would need to combine this with the contextual, organisation-provided knowledge. Thus, while the organisations would want to leverage the project professional's dependence on its resources, they are also in turn dependent on the project professional who would combine their generic expertise in project management with organisation-specific knowledge (Alvesson, Robertson, \& Swan 2001).

Once we have understood the nature and foci of commitment, it makes sense to ask what are the determinants of commitment? While there are numerous antecedents of commitment - personal variables such as age, gender and managerial behavior; and organisational variables, such as nature of work, job design and human resource policies, (Gonzales \& Guillen, 2008) — we will concern ourselves with 'work motivation' as a determinant of OC and PC. We will begin the discussion on work motivation by briefly referring to the theories of work motivation that are broadly divided as internal and external theories of motivation. The internal motivation theories include the need-based, intrinsic and self-determination theories of motivation, and the external theories (of motivation) include cognitive or process-based theories of motivation ( Dwivedula \& Bredillet $2010^{1}$; also see Kanfer, 1992 for a detailed discussion of this typology).

\section{Work motivation}

Internal motivation

Internal motivation theories primarily include the need-based (Maslow 1946; McClelland 1961; Alderfer 1972), and self-determination theories (Deci \& Ryan 1985; Ryan \& Deci 2000) of motivation. Internal motivation has its roots in the works of Freud (1940), Viteles (1932) and Maier (1946) and has largely been studied from a biological or psychological perspective. This formed the basis for the need-based theories of motivation that gained popularity in subsequent years. The central point of these theories was the satisfaction of individuals' needs at the workplace influenced by their own behaviour. This line of research was extended by social psychologists such as Deci (1975), Turner (1978), and Greenwald and Pratkanis (1984). They proposed the idea of intrinsic motivation, which includes individual motives related to one's self or identity (expressed in the form of traits, competencies values etc). Individuals will constantly

\footnotetext{
${ }^{1}$ This material is reproduced with permission of John Wiley \& Sons, Inc
} 
refer to their self and will demonstrate only those behaviours that are consistent with their self. Later, Tajfel (1982), through his 'social-identity theory', and Deci and Ryan (1985), through their 'self-determination theory', suggested that individuals will gravitate towards social groups (organisations or occupational groups) that complement their values; so much so, that individuals internalise the values of the referent social group with their own self. This is called internalisation and has been known to produce strong affective commitment (Gagne \& Deci 2005; Meyer et al 2004 as cited in Johnson, Chang \& Yang 2010).

Job design and how the perceptions of job design determine individual behaviour was also investigated in a parallel stream of research. The earliest known studies on job design can be traced back to the ideas of job simplification (Smith 1776) and scientific management (Taylor 1911). But the psychological impact of job design was posited by Vernon, Wyatt and Ogden (1924), and later by Davis and Canter (1956), who popularised job design techniques such as rotation, enlargement and enrichment. This line of research was further strengthened by the studies conducted at the Tavistock Institute, which proposed the socio-technical systems approach of job design (STS, Bostrom \& Heinen 1977). Various principles of job design such as employee training, empowerment, information exchange and quality of work life were found to be important to motivate employees. Similar propositions were made by the Job Charactersitics Model (Hackman \& Oldham 1976) that identified five job dimensions —skill variety, task identity, task significance, autonomy and feedback — as being important for job satisfaction and productivity.

Thus, together, the concept of self, and job design defined individuals' motives, and therefore the influence on the behaviour.

External motivation

Motives based on external rewards are explained through the individual's cognition of the rewards obtained. The central tenet to these theories is an actor's desire to adjust or regulate his or her behavior based on the satisfaction with the rewards (Bandura 1977). This approach assumes the automatic influence of rewards and feedback on work as drivers to work motivation. This relationship is moderated by the cognitive and affective elements of the actor (Carver \& Scheier 1981). The cognitive component consists of the actor's efforts to juxtapose his or her current state with the goals. These goals are internal to the actor. On the other hand, the affective component is defined by the actor's behavior to reduce the discrepancy between the current and desired states (Klein 1989). Numerous theories subscribing to this position were proposed especially in the latter half of the previous century (c.f. expectancy theory, Vroom 1964; equity theory, Adams 1963; goal-setting theory, Locke 1968); social-cognitive theory, Bandura 1977; control theory, Klein 1989).

Expectancy theory (Vroom 1964) and equity theory (Adams 1963) assume that individuals evaluate the outcomes of their efforts, and in turn will adjust their behaviour to achieve a parity between the efforts expended and the outcomes achieved. A similar premise is put forward by Edwin Locke's goal-setting theory (1968), which states that the individual's behavior is modified by the difficulty of the goal to be achieved. The higher the level of difficulty, and specificity of the goal, the greater the individual's motive to achieve the goal. However, this relationship is 
moderated by the individual's commitment to the goal. The higher the degree of the individual's commitment to the goal, the greater the effort expended in achieving the goal.

Thus, the external motivation school maintains that the relationship between an individual's motives and behaviour (which in this case is OC or PC) is moderated by the individual's affection for and cognition of the outcomes. This includes the individual's proclivity for rewards, and also how the individual adjusts the efforts in relation to the outcomes achieved.

The discussion on the internal and external basis of motivation concludes that work motivation is a multidimensional concept. While internal motivation seems to rely on actors' volition to predict their behaviours (one of which can be commitment), external motivation relies on the actors' cognition of their work environment (such as fairness of rewards against the efforts expended). This cognition leads the actors to adjust their behavior. With this understanding, in the following section, we contend that: (i) since the motivational basis of the actor's behaviour are different, the actor will demonstrate different types of commitment (either affective, continuance or normative) towards the organisation and profession; (ii) the typical nature of temporary organisations - time, task, team and transition — will influence the actor's volition and cognition. Therefore, one or more of these characteristics will moderate the relationship between work motivation (as a proposed independent variable), and OC and PC (as proposed dependent variables).

Recent research on work motivation in temporary organisations Rigorous studies on work motivation are scant in the project management literature. However, some effort has been made to address this shortcoming. For example, Schmid \& Adams 2008) identified factors affecting employee motivation from a sample of 115 project professionals in Australia. External motivating factors such as providing feedback on employee's performance and ease of communication between the team members is motivating to the employees. Other external rewards such as perceived fairness of rewards and financial incentives were also found to be motivating (Rose \& Manley 2009). The role of financial incentives in motivating employees is further explained by Rose and Manley (2011). Four large-scale construction projects in Australia were studied using the inductive case method. Three major types of financial incentives - share of savings, schedule incentives and performance bonuses - were studied for their influence on employee motivation. This study concluded that designing flexible incentives, adjusted to the project conditions is most motivating to the employees. Furthermore, the project workers would have some control over how the team-based rewards would be distributed.

On internal rewards, Hertel, Niedner and Herrmann (2003), and more recently Sharp, et al (2008) and Seiler, et al (2011) suggest that the nature of tasks, autonomy at work and task significance are more motivating than financial rewards. Similar results were also suggested by Dwivedula and Bredillet (2010). Opportunities to apply advanced knowledge and perform competency-enhancing tasks are perceived to be motivating by project workers. 


\section{Propositions}

Internal motivation, $O C$ and $P C$

The review of the literature on permanent organisations has revealed two bases for intrinsic motivation: (i) Internalisation or personalisation of organisational values by the individual, and

(ii) work characteristics. For example, Andolsek and Stebe (2004) studied a global sample of 500 respondents as a part of an International Social Survey Program project. They studied the moderating effects of an individual's values on the relation between intrinsic motivation and three types of OC. Using the competing values framework (Quinn \& Rohrbaugh 1981) as the theoretical lens, they posit that actors who have high individualistic values and low materialistic values tend to be affectively committed to their organisations. High levels of individualistic values alone will also lead to increased continuance commitment. Similarly, Behery (2009) used person-organisation fit theory (Kristof 1996) to demonstrate the moderating role of personalisation on the relation between job characteristics and OC. From a sample of 960 respondents working with 16 large companies in the United Arab Emirates (which included investment and banking, insurance, real estate and retail industries), he concluded that the greater the extent of personalisation of values between employees and their organisations, the stronger the employees' affective OC. A few studies also reported the contrary, where personalisation was only found to partially influence OC (Ugboro 2006). A few other studies also identified intrinsic motivation to be determinant of affective, continuance and normative OC; however, the moderating variables were not considered (c.f. van Vuuren, et al, 2008).

Research on temporary organisations seems to consider the same arguments to present the relationship between intrinsic motivation and OC. We also note that personalisation of values is an outcome of the actor's volition. Interestingly, in temporary organisations, values seem to be defined in terms of the nature of work. For example, Chang, Choi and Kim (2008) studied 132 research and development professionals in a Korean electronics firm. They concluded that individuals have intrinsic work values such as opportunity to learn, autonomy at work, challenging nature of work, and professional networking. These work values are a determinant of the employees' OC. This relationship between intrinsic work values and OC is moderated by the work context. If the context is controlling, professionals with high intrinsic values will find the environment less satisfying, and therefore more likely to leave the organisation. Similar results are reported by Kochanski and Ledford (2001), who studied 210 high-tech scientists and engineers to propose that work content is an important determinant of OC, as it satisfies intrinsic needs rather than instrumental needs.

Projects are typically undertaken to execute non-routine processes. Hence, they are characterised by discontinuity, uniqueness and complexity (Cova \& Salle 2005; Skaates \& Tikkanen 2003). Projects also call for application of highly specialised skills as they include interaction between multiple stakeholders. Further, the work itself provides discretion, technical autonomy and creative freedom to the project workers. While this may be motivating to the project workers, previous research has also shown that highly skilled workers who are engaged in temporary employee arrangements such as projects may not identify completely with the organisation as they are less dependent on the organisation for incentives. Further, the skills that they have acquired are role specific rather than organisation centric (Westenholz 2006). Workers assigned for a limited period of time experience lower levels of task significance and autonomy, and 
receive less frequent feedback on their work compared with their counterparts with more permanent employment arrangements (Ang \& Slaughter 2001).

Therefore, we contend that as project workers are assigned for a limited period of time, they are less likely to identify with the organisation and demonstrate lower affective OC than permanent workers.

Proposition 1a. The relation between the actor's needs and affective OCis moderated by the extent of personalisation of actor's values with that of the organisation.

Proposition $1 b$. The relation between the actor's needs and affective PC is moderated by the extent of personalisation of actor's values with that of the profession.

Proposition 1c. The relation between the actor's needs and affective OC is moderated by the actor's tenure of employment in the organisation.

Proposition 1d. Actors employed in temporary organisations will demonstrate lower affective OC compared with actors employed in permanent organisations due to shorter organisational tenure in temporary organisations.

As discussed earlier, apart from an actor's congruence of values with the organisation, one's volition to be associated with a particular social group is also a determinant of commitment. Previous research indicates that tenure of employment determines the strength of association between an actor and his or her social group. Homans (1961), and Salanick and Pfeffer (1978) suggest that group members who spend more time together tend to share history with each other and develop a collective identity. This was explained further by Abigail and Scholarios (2007). From a study of information technology workers engaged in projects, they found that employees chose to be associated with an 'elitist' group such as 'information technology workers' rather than with the organisation. Similarly, Wang and Armstrong (2004) compared the OC and occupational commitment of project workers. They reported that a project worker greatly values the reputation of being associated with the project management community as this implies an opportunity to learn and apply advanced knowledge.

A contradictory finding by Wang (2001) suggests that project workers may not closely associate with the project management profession. This is because, as in case of permanent organisations, individual job descriptions may not be available for project management professionals. However, given the growing popularity of project management (demonstrated by the increase in memberships in professional associations, professional certifications and project management standards), this observation may not be well founded. However, a hindrance to the development of a shared identity among actors working together for a limited period of time as in case of projects is explained by Cunningham and Sagas (2004). They argue that when homogenous groups of individuals enter the organisation at the same time, they would be exposed to similar experiences. As a result of this socialisation, they share a sense of identity with the organisation (see Bryne, 1971 for a discussion of the similarity-attraction paradigm). 
Previous research has shown that socialisation shapes the normative commitment of an actor. The social experiences of actors (with the organisation or a professional community) helps the actors to know what is valued and expected of them when working within that social group (Weiner 1982; Eisenberger et al 2001). However, projects are managed by workers with complementary skills rather than homogenous skills. Creation of a shared sense of identity among these diverse actors working together for a limited period of time will be a challenge. Therefore, the actor's normative commitment towards the organisation will be low as compared to their normative professional commitment.

Proposition 2a. Shorter organisational tenure leads actors in temporary organisations to demonstrate lower normative OC compared with actors employed in permanent organisations.

Proposition 2b. A stronger shared sense of identity towards the profession leads actors working in temporary organisations to demonstrate higher normative PC than normative OC.

External motivation, $O C$ and $P C$

Our literature review shows that the concept of 'rewards' has been well established both in the organisational behavior literature (through the various motivational theories) and in the human resource management research (as indicated by performance management practices (Kroumova \& Lazarova 2009). Predominantly, the emphasis seems to be on financial rewards, and career development. Further, an actor's perception of equity of reward is the regulatory variable between rewards obtained and OC. The central argument is that perceptions of fairness of rewards affects employee attitudes and therefore their behavior towards their organisation (Kim and Leung 2007).

Using self-determination theory as a framework, Gellatly, et al (2009) conducted a survey of 332 alumni of a leading Canadian business school. They argued that financial rewards positively correlated with affective OC but negatively correlated with continuance OC. In this case, the employees' perception of fairness of the rewards moderated the relationship. Similar results were reported by Malhotra, Budhwar and Prowse (2007). From their study of 342 employees working in four United Kingdom-based call centers, they concluded opportunities for career development and financial rewards to be determinants of affective commitment, while financial incentives alone were a determinant of normative commitment. There have also been studies that suggest a positive relation between monetary rewards and affective commitment, although the regulatory variables are not considered (Karatepe, Yavas \& Babakus 2007).

On the other hand, a few studies also reported the lack of influence of rewards on OC (Chew \& Chan 2008). Restubog, Bordia and Bordia (2009) contend that perceived fairness of rewards did not significantly predict affective commitment. Likewise, career development may also not be important to foster employee commitment (Moynihan \& Pandey 2007).

Rewards as a determinant of OC is well documented even in temporary organisations. For example, in a study of 1154 employees working in an aerospace company with headquarters in southern California in the United States, perceptions of fairness and perceived control were 
found to be strong determinants of OC (Brockner, et al 2004). The organisation was downsizing its workforce. It was found that perceived control (ability to physically and psychologically counteract the harmful effects of threat) moderated the relationship between fairness of rewards and OC. OC was particularly high among the workers whose perceived control was high. Similar results were reported by Ahuja, et al (2007), who showed that perceived fairness of rewards significantly predicts OC.

Apart from fairness of compensation, additional constructs of employment conditions were also tested for their influence on OC. Using psychological contract theory (Rousseau 1990) as a framework, Harris, et al (2009) from their study of 415 information systems / information technology professionals suggest that job security, individual rewards (including compensation and new opportunities) are determinants of OC.

Previous research suggests that an actor's length of association with the organisation determines his or her perceptions of fairness of the rewards (Soon \& Slaughter 2001). Previous research shows that workers employed for shorter duration of time with the organisation experience greater job instability and fewer opportunities for career advancement ( Amuedo-Dorantes, Malo $\&$ Munoz-Bullon 2008). For example, from their study of 103 information systems development workers (comprised of 81 in-house, and 21 contract workers), Raghavan, Sakaguchi \& Mahaney (2008) found that non-permanent employees (such as the contract workers) reported lower perceived fairness of rewards compared with the permanent employees. In yet another study, Loi, Hang-yue and Foley (2006) observed that permanent workers and those associated with the organisation for a longer period of time demonstrated greater commitment towards the organisation.

Based on this discussion, we argue that rewards determine an actor's normative commitment towards the organisation. Further, this relationship is moderated by the actor's perceived fairness of rewards.

Proposition 3a. The relation between rewards and normative OC is moderated by the actor's perceived fairness of rewards.

The above discussion and the proposed research model is summarised in figures 1 and 2 . Figure 1 is the conceptual model that presents the relationship between work motivation, OC and PC. Figure 2 presents the relationship between the OC and PC in temporary and permanent organisations. 


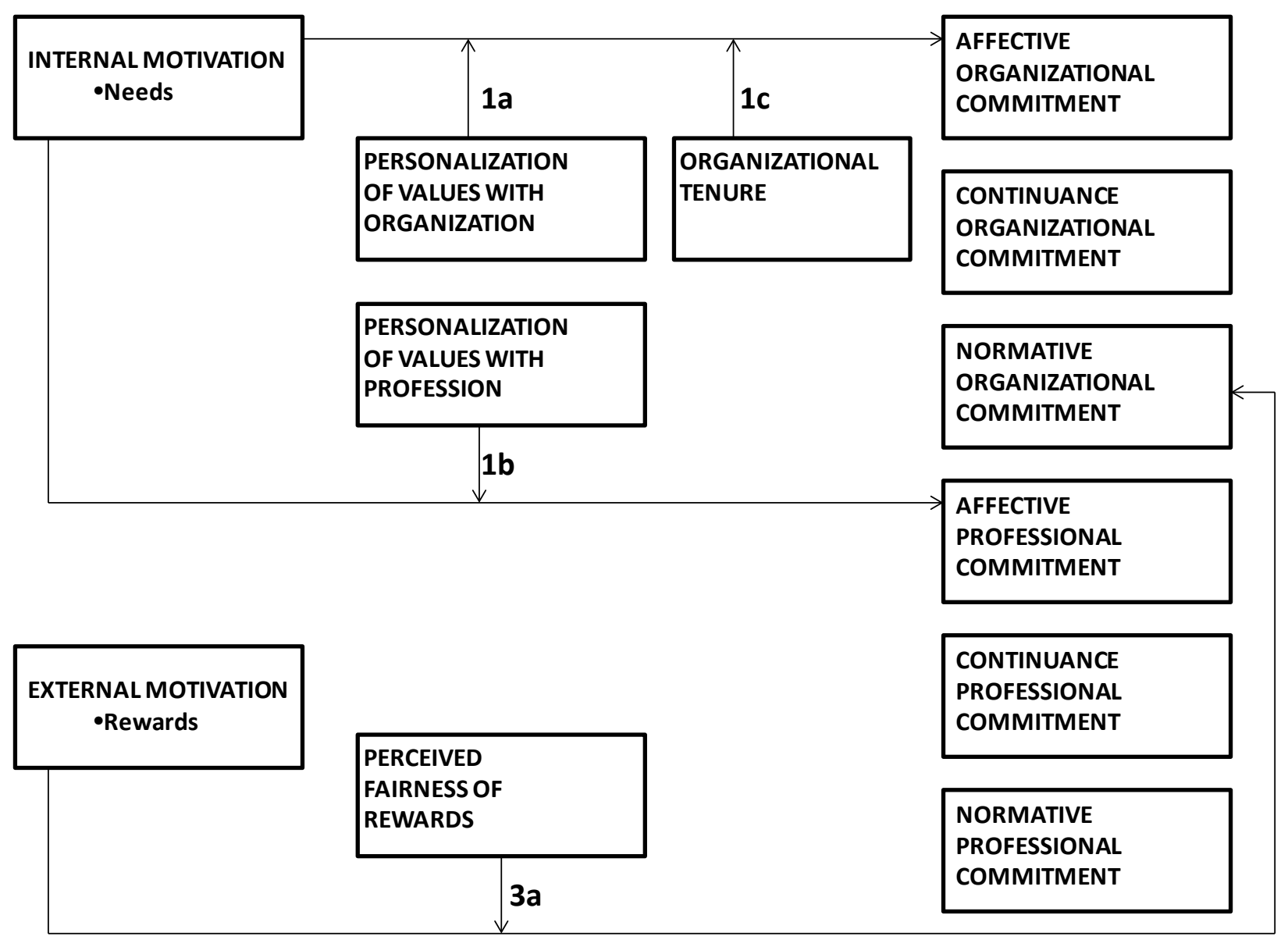

Figure 1. Conceptual model of work motivation as an antecedent of organisational commitment and professional commitment 


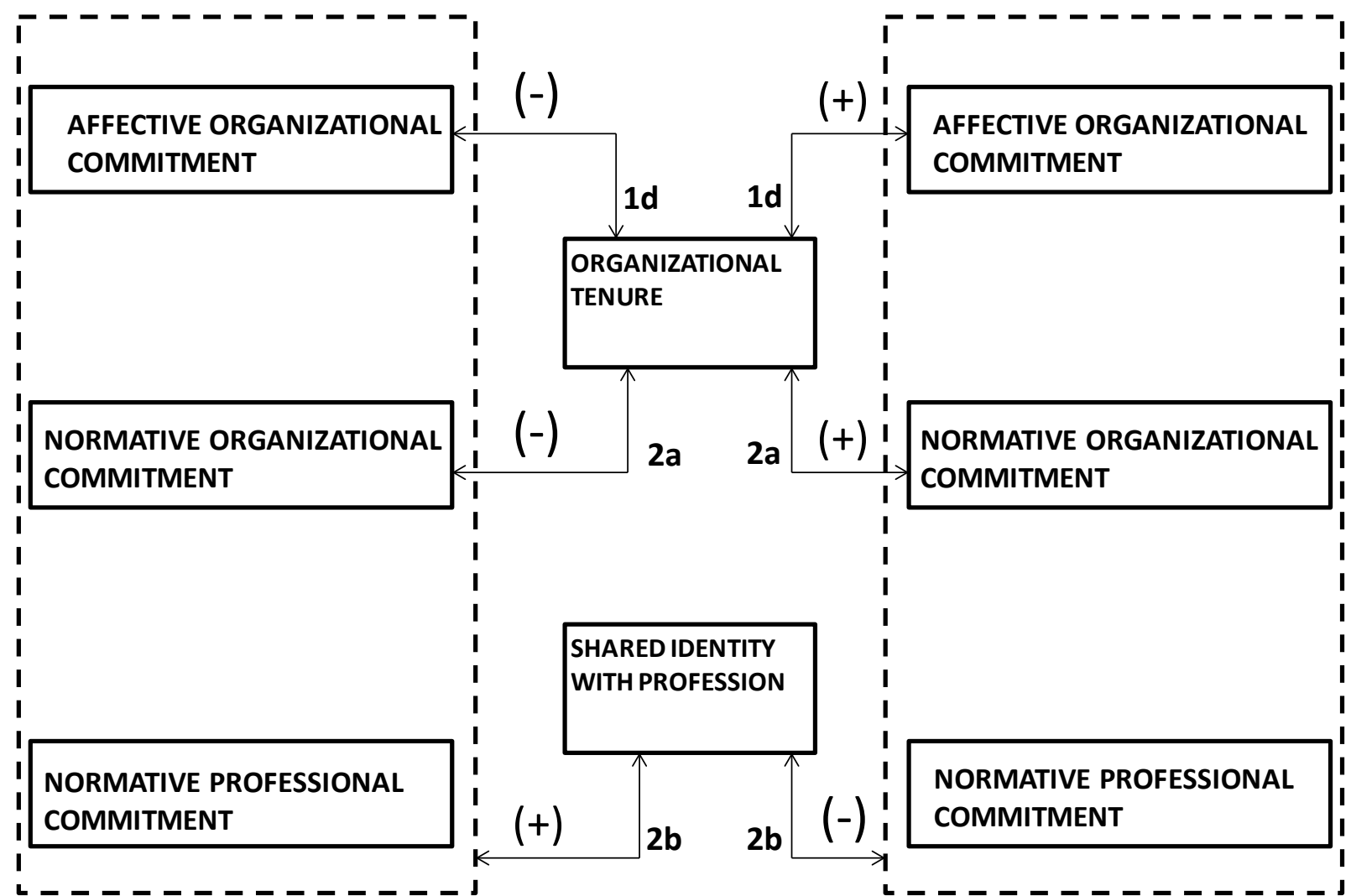

Figure 2. Relation between the constructs of organisational commitment and professional commitment in case of temporary and permanent organisations

\section{Future research}

At the broader discipline level, we note that there is increasing interest to understand how the various sub-domains of management influence project management. This is evident from the research on the theory of project management (Anbari 1985; Söderlund 2002; Bredillet 2004, and Turner et al 2010), where operations research, finance, strategy, marketing and organisational behavior have influenced research themes in project management. This has also lead to cross fertilisation of ideas between the sub-domains of management and project management. Our research study is one such example, where we have significantly drawn from the organisational behavior literature to understand the motives and working relationships in a specific type of organisational structure - the temporary organisation. Organisational structure has been shown to determine work-related attitudes.

The purpose of the current paper is to present the theoretical framework and review the literature on the relationship between work motivation, OC and PC in temporary organisations and especially projects. From the literature review, we observe that research focusing on the antecedents of affective OC and PC has been done. Some research identifying external rewards as a determinant of normative OC is also presented. However, more research considering motivation as a determinant of other forms of OC and PC is needed. On the other hand, we also 
observed that only the moderating effects of time, and partially task, have been directly considered when evaluating the influence of motivation on commitment. Other characteristics of temporary organisations - team and transition — have not been investigated. Hence our future research will focus on conducting a rigorous empirical study on motivation and its relationship to OC and PC. For motivation, we will consider two constructs - internal motivation and external motivation. For OC and PC, we will consider three states of commitment - affective, continuance and normative - as the constructs. We intend to conduct a cross-sectional study by considering project-based organisations from various industries. While the issues of generalisation of results will be raised for such as study, it will provide us with initial findings. These initial findings will subsequently lead to longitudinal studies where mixed research methodologies may be applied.

\section{Conclusion}

The lack of focus to investigate the motivational basis of OC and PC in temporary organisations has presented a notable weakness. Through this study, we wish to contribute to an understanding of how the characteristics of a temporary organisation moderate the relationship between work motivation, OC and PC. Overall, our review of theory and literature suggests that the length of tenure (in an organisation) and sense of identification (with a profession or an organisation) that is brought about by the task regulates the relationship between work motivation and affective OC and PC. Further, an actor's perception of fairness of rewards and a shared sense of identity also explain the high normative PC and low normative OC in temporary organisations. However, the effects on continuance commitment are yet to be investigated by the research community. Thus, the study provides a better insight to explain the nature of commitment in temporary organisations and highlight the differences with permanent organisations. It is expected that the study would have direct implications for employee engagement in temporary organisations and indirect implications for managing their performance.

\section{References}

Abigail, M. \& Scholarios, D. 2007, Revisiting technical workers: professional and organisational identitites in the software industry, New Technology, Work, and Employment, vol. 22, no. 2, 98-117.

Adams, J.S. 1963, Toward an understanding of inequity, Journal of Abnormal Social Psychology, vol. 67, 422-436.

Ahimbisibwe, A. \& Nangoli, S. 2012. Using the behavioral factors to explain the perceived project performance of Ugandan citizenship projects: a multivariate analysis, International Journal of Business and Social Science, vol. 3, no. 10, 208-224.

Ahuja, M.K., Chudoba, K.M., Kacmar, C. McKnight, D.H. \& George, F. 2007, IT road warriors: balancing workfamily conflict, job autonomy, and work overload to mitigate turnover intentions, MIS Quarterly, vol. 31, no. 1, 1-17.

Alderfer, C.P. 1972, Existence, Relatedness, and Growth, Free Press New York.

Allen, N.J. \& Meyer, J.P.1990, The measurement and antecedents of affective, continuance, and normative commitment to the organization', Journal of Occupational Psychology, vol. 63, 1-18.

Alvesson, M., Robertson, M. \& Swan, M. 2001, The best and the brightest. The role of elite identity in knowledge intensive companies, paper presented at the 2nd International Critical Management Studies Conference, 1112 July, Manchester, England.

Amuedo-Dorantes, C., Malo, M. \& Munoz-Bullon-F. 2008, The role of temporary help agency employment on temp-to-perm transitions, Journal of Labor Research, vol. 29, no. 2, 138-161.

Anbari, F.T. 1985, A systems approach to project evaluation, Project Management Journal, vol. XVI, no. 3, 21-26.

Andolsek, D.M. \& Stebe, J. 2004, Multinational perspectives on work values and commitment, International Journal of Cross Cultural Management, vol. 4, no. 2, 181-220.

Andersen, E.S. 2006, Toward a project management theory for renewal projects, Project Management Journal, vol. 37, no.4, 15-30. 
Ang, A. \& Slaughter, S. 2001, Work outcomes and job design for contract versus permanent information systems professionals on software development teams, Management Information Systems Quarterly, vol. 25, no. 3, 321-350.

Bandura, A. 1977, Social Learning Theory, Prentice-Hall: Engelwood Cliffs, NJ.

Becker, H. 1960, Notes on the concept of commitment, American Journal of Sociology, vol. 66, 32-44.

Becker, T. \& Billings, R. 1993, Profiles of commitment: an empirical test, Journal of Organizational Behavior, vol. $14,177-190$.

Becker, T.E., Billings, R.S., Eveleth, D.M. \& Gillbert, N.L. 1996, Foci and bases of employee commitment: Implications for job performance, Academy of Management Journal, vol. 39, no. 2, 464-482.

Beckhy, B.A. 2006, Gaffers, gofers, and grips: role-based coordination in temporary organizations, Organization Science, vol. 17, no.1, 3-21.

Behery, M.H. 2009, Person/organization job-fitting and affective commitment to the organization: perspectives from the UAE, Cross Cultural Management: An International Journal, vol. 16, no. 2, 179-196.

Bostrom, R.P. \& Heinen, J.S. 1977, MIS problems and failures: a socio-technical perspective, Part 1: the causes, MIS Quarterly, vol. 1, no. 3, 17-32.

Bredillet, C.N. 2004, Beyond the positivist mirror: towards a project management Gnosis, paper presented at IRNOP VI Conference, 25-27 August, Turku, Finland.

Bredillet, C. 2010, Blowing hot and cold on project management, Project Management Journal, vol. 41, no. 3, 4-20.

Brockner, J., Spreitzer, G., Mishra, A., Hochwarter, W., Pepper, L. \& Weinberg, J. 2004, Perceived control as an antidote to the negative effects of layoffs on survivors' organizational commitment and job performance, Administrative Science Quarterly, vol. 49, 76-100.

Bryne, D. 1971, The Attraction Paradigm, Academic Press: New York.

Carver, C.S. \& Scheier, M.F. 1981, Attention and Self-regulation: A Control-theory Approach to Human Behavior, Springer-Verlag: NewYork.

Chang, J.Y., Choi, J.N. \& Kim, M.U. 2008, Turnover of highly educated R\&D professionals: the role of pre-entry cognitive style, work values, and career orientation, Journal of Occupational and Organizational Psychology, vol. 81, 219-317.

Chew, J. \& Chan, C.A. 2008, Human resource practices, organizational commitment, and intention to stay, International Journal of Manpower, vol. 29, no. 6, 503-522.

Cicmil, S. \& Hodgson, D. 2006. New possibilities for project management theory: a critical engagement, Project Management Journal, vol. 37, no. 3, 111-122.

Corley, M.C. \& Mauksch, H.O. 1993, The nurse's multiple commitments, Journal of Professional Nursing, vol. 9, no. 2, 116-122.

Cova, B. \& Salle, R. 2005, Six key points to merge project marketing into project management, International Journal of Project Management, vol. 23, 354-359.

Cunningham, G.B. \& Sagas, M. 2004, Group diversity, occupational commitment, and occupational turnover intentions among NCAA Division IA football coaching staffs, Journal of Sports Management, vol. 18, 236254.

Davis, L.E. \& Canter, R.R. 1956, Job design research, Journal of Industrial Engineering, vol. 7, 275-282.

Deci, E.L. 1975, Intrinsic Motivation, Plenum: New York.

Deci, E.L. \& Ryan, R.M. 1985, Intrinsic Motivation and Self-determination in Human Behavior, New York: Plenum: New York.

DeFillippi, R. \& Arthur, M. 1998, Paradox in project-based enterprise: the case of film making. California, Management Review, vol. 40, no. 2, 147-160.

Dutton, J.E., Dukerich, J.M. \& Harquail, C.V. 1994, Organizational images and member identification, Administrative Science Quarterly, vol. 39, no. 2, 239-263.

Dwivedula, R. \& Bredillet, C. 2010, The relationship between organizational and professional commitment in the case of project workers: Implications for project management, vol.41, no. 4, 79-88.

Dwivedula, R., Bredillet, C. \& Müller, R. 2012, The relation between work motivation and project management success in case of temporary organizations: theoretical lenses, Academy of Business Research Journal, vol. 2, no. 1, 43-66.

Eisenberger, R., Armeli, S., Rexwinkel, B., Lynch, P.D. \& Rhoades, L. 2001, Reciprocation of perceived organizational support, Journal of Applied Psychology, vol. 86, 42-51.

Finley, A.P., Mueller, C.W. \& Gurney, C.A. 2003, Organizational and professional commitment in professional and non-professional organizations: the case of nurse doctorates, Research in Social Stratification and Mobility, vol. 20, 325-358. 
Freud, S. 1940, An Outline of Psychoanalysis. The Standard Edition of the Complete Psychological Works of Sigmund Freund, Vol. XXIII, Hogarth Press: London.

Gagne, M. \& Deci, E.L. 2005, Self-determination theory and work motivation, Journal of Organizational Behavior, vol. 26, 331-362.

Gellatly, I.R., Hunter, K.H., Currie, L.G. \& Irving, P.G. 2009, HRM practices and organizational commitment profiles, International Journal of Human Resource Management, vol. 20, no. 4, 869-884.

Gibson, C.B. \& Cohen, S.G. 2003, The last word: conclusions and implications, in C.B. Gibson \& S.G. Wilson (eds), Virtual Teams that Work: Creating Conditions for Virtual Team Effectiveness, Jossey-Bass: San Francisco, pp. 403-421.

Gonzales, T.F. \& Guillen, M G. 2008, Organizational commitment: a proposal for wider ethical conceptualization of 'normative commitment', Journal of Business Ethics, vol. 78, 401-414.

Greenwald, A.G. \& Pratkanis, A.R. 1984, The self, in R.S. Wyer \& T.K. Srull (eds.), Handbook of Social Cognition, Erlbaum: Hillsdale, NJ, pp. 129-178.

Hackman, J.R. \& Oldham, G. 1976, Motivation through the design of work: test of a theory, Organizational Behavior and Human Performance, vol. 16, 250-279.

Harris, M.T., Klaus, J., Blanton, E. \& Wingreen, S.C. 2009, Job security and other employment considerations as predictors of the organizational attitudes of IT professionals, International Journal of Global Management, vol. 1, no.1, 32-45.

Haslam, S.A., Eggins, R.A. \& Reynolds, K.J. 2003, The ASPIRe model: actualizing social and personal identity resources to enhance organizational outcomes, Journal of Occupational and Organizational Psychology, vol.76, 83-113.

Hertel, G., Niedner, S. \& Hermann, S. 2003, Motivation of software developers in open source projects: An internetbased survey of contributors to the Linux kernel, Research Policy, vol. 32, 1159-1177.

Homans, G. 1961, Managing the New Team Environment, Addison-Wesley: Reading, MA.

Johnson, R.E., Chang, C.-H. \& Yang, L. 2010, Commitment and motivation at work: the relevance of employee identity and regulatory focus, Academy of Management Review, vol. 35, 226-245.

Kanfer, R. 1992, Work motivation: New directions in theory and research, in C.L. Cooper \& I.T. Robertson (eds.), International Review of Industrial and Organizational Psychology, vol.7,John Wiley \& Sons: London, pp.1-53.

Karatepe, O.M., Yavas, U. \& Babakus, E. 2007, The effects of customer orientation and job resources on frontline employees' job outcomes Services Marketing Quarterly, vol. 29, no. 1, 61-79.

Karin, F. \& Birgit, S. 2007, Work satisfaction, organizational commitment and withdrawal behaviors, Journal of Management Research, vol. 30, no. 10, 708-723.

Kim, T. \& Leung, K. 2007, Forming and reacting to overall organizational fairness perceptions: a cross-cultural comparison, Organizational Behavior and Human Decision Processes, vol.104, 83-95.

Klein, H.J. 1989, An integrated control theory model of work motivation, The Academy of Management Review, vol. 14, no. 2, 150-172.

Kochanski, J. \& Ledford, G. 2001, 'How to keep me’ — retaining technical professions, Research Technology Management, vol. 44, no. 3, 31-38.

Kristof, A.L. 1996, Person-organization fit: an integrative review of its conceptualizations, measurement, and implications, Personnel Psychology, vol. 49, no. 1, 1-49.

Kroumova, M.K. \& Lazarova, M.B. 2009, Broad-based incentive plans, HR practices and company performance, Human Resource Management Journal, vol.19, no. 4, 355-374.

Kuhn, T.S. 1970, The Structure of Scientific Revolutions, Chicago University Press: Chicago, IL.

Leybourne, S.A. 2007, The changing bias of project management research: a consideration of the literatures and an application of extant theory, Project Management Journal, vol. 38, no.1, 61-73.

Limsila,K. \& Ogunlana, S.O.2007, Performance and leadership outcome correlates of leadership styles and subordinate commitment, Engineering Construction and Architectural Management, vol. 15, no. 2, 164184.

Locke, E.A. 1968, Toward a theory of task motivation and incentives, Organizational Behavior and Human Performance, vol. 3, 157-189.

Locke, E.A., Shaw, K,N., Saari, L.M. \& Latham, G.P. 1981, Goal setting and task performance: 1969-1980, Psychological Bulletin, vol. 90, no. 1, 125-152.

Loi, R., Hang-Yue, N. \& Foley, S. 2006, Linking employees' justice perceptions to organizational commitment and intention to leave: the mediating role of perceived organizational support, Journal of Occupational and Organizational Psychology, vol. 79, 101-120. 
Lundin, R.A. \& Söderholm, A. 1995, A theory of the temporary organization, Scandinavian Journal of Management, vol. 11, no. 4, 437-455.

Maier, N.R.F. 1946, Psychology in Industry, Houghton-Mifflin: Boston, MA.

Malhotra, N., Budhwar, P. \& Prowse, P. 2007, Linking rewards to commitment: an empirical investigation of four UK call centres, International Journal of Human Resource Management, vol. 18, no. 2, 2095-2128.

Maslow, A. 1946, A theory of human motivation, Psychological Review, vol. 50, 370-396.

Mathieu, J. \& Hamel, K. 1989. A causal model of the antecedents of organizational commitment among professionals and nonprofessionals, Journal of Vocational Behavior, vol. 34, no. 3, $299-317$.

McClelland, D.C. 1961, The Achieving Society, Van Nostrand: Princeton, NJ.

Meyer, J.P. \& Allen, N.J. 1997, Commitment in the Workplace: Theory, Research, and Application, Sage: Thousand Oaks, CA.

Meyer, J.P., Allen, N.J. \& Smith, C.A. 1993, Commitment to organizations and occupations: extensions and test of a three-component conceptualization, Journal of Applied Psychology, vol. 78, no. 4, 538-555.

Meyer, J.P., Becker, T.E. \& Vandenberghe, C. 2004, Employee commitment and motivation: a conceptual analysis and integrative model, Journal of Applied Psychology, vol. 89, no. 6, 991-1007.

Meyer, J.P. \& Herscovitch, L. 2001, Commitment in the workplace: toward a general model, human resource, Management Review, vol. 11, 299-326.

Moynihan, D.P. \& Pandey, S.K. 2007, The role of organizations in fostering public service motivation ,Public Administration Review, vol. 67, no. 1, 40-53.

Powell, W.W. 1990, Neither market nor hierarchy: network forms of organization, in B. Staw \& R.M. Kanter (eds.), Research in Organizational Behavior, vol.12, p. 295-336, JAI Press: CT, USA.

Quinn, R.E. \& Rohrbaugh, J. 1983, A spatial model of effectiveness criteria: towards a competing values approach to organizational analysis, Management Science, vol. 29, no. 3, 363-377.

Raghavan, V.V., Sakaguchi, T. \& Mahaney, R.C. 2008, Organizational justice perceptions and their influence on information systems development project outcomes, Journal of Information Technology Theory and Application (JITTA), vol. 9, no. 2, 27-43.

Restubog, S.L.D., Bordia, P. \& Bordia, S. 2009, The interactive effects of procedural justice and equity sensitivity in predicting responses to psychological contract breach: an interactionist perspective, Journal of Business and Psychology, vol. 24, 165-178.

Rose, T.M. \& Manley, K. 2010, Motivation toward financial incentive goals on construction projects, Journal of Business Research, vol. 64, no. 7, 765-773.

Rousseau, D.M. 1990, New hire perceptions of their own and their employer's obligations: a study of psychological contracts, Journal of Organizational Behavior, vol. 11, no. 5, 389-400.

Ryan, R.M. \& Deci, E.L. 2000, Self-determination theory and the facilitation of intrinsic motivation, social development, and well-being, American Psychologist, vol. 55: 68-78.

Salanick, G. \& Pfeffer, J. 1978, A social information processing approach to job attitudes and task design, Administrative Science Quarterly, vol. 23, 224-253.

Sandberg, J. \& Alvesson, M. 2011, Generating research questions through problematization, Academy of Management Review, vol. 36, no. 2, 247-271.

Schmid, B. \& Adams, J. 2008, Motivation in project management: the project manager's perspective, Project Management Journal, vol. 39, no. 2, 60-71.

Sharp, H.N., Baddoo, S., Beecham, T., Hall, T. \& Robinson, H. 2008, Models of motivation in software engineering, Information and software technology, vol. 5, no. 1, 219-233.

Skaates, M. \& Tikkanen, H. 2003, International project marketing: an introduction to the INPM approach, International Journal of Project Management, vol. 21, no. 7, 503-510.

Smith, A. 1776/1974, The Wealth of Nations, Penguin: Harmondsworth, Middlesex.

Söderlund, J. 2002, On the development of project management research: schools of thought and crtique', International Journal of Project Management, vol. 6, no. 1, 20-31.

Somers, M.J. 2010, Patterns of attachment to organizations: commitment profiles and work outcomes, Journal of Occupational and Organizational Psychology, vol. 83, no. 2, 443-453.

Soon, A., Slaugher, S.A. 2001. 'Work outcomes and job design for contract versus permanent information systems professionals on software development teams', MIS Quarterly, vol. 25,no.3, 321-350

Tajfel, H. 1982, Social psychology of intergroup relations, Annual Review of Psychology, vol. 33, 1-39.

Taylor, F.W. 1911, The Principles of Scientific Management, Harper \& Brothers: New York.

Turner, J.C. 1978, Social categorization and social discrimination in the minimal group paradigm, in Tajfel, H. (ed.), Differentiation Between Social Groups, Academic Press: London, pp. 101-140. 
Turner, J.R. \& Müller, R. 2003, On the nature of the project as a temporary organization, International Journal of Project Management, vol. 21, no. 1, 1-7.

Turner, R., Huemann, M., Anbari, F. \& Bredillet, C. 2010, Perspectives on Projects, Routledge: New York.

Ugboro, I.O. 2006, Organizational commitment, job redesign, employee empowerment, and intent to quit among survivors of restructuring and downsizing, Journal of Behavioral and Applied Management, vol. 7, no. 3, p. 232-257.

van Vuuren, H.A., Veldkamp, B.P. de Jong, M. \& Seijdel, E. 2008, Why work? Aligning foci and dimensions of commitment along the axis of competing values framework, Personnel Review, vol. 37, 47-75.

Vandenberghe, C. \& Tremblay, M. 2008, The role of pay satisfaction and organizational commitment in turnover intentions: a two-sample study, Journal of Business Psychology, vol. 22, 275-286.

Vernon, H.M., Wyatt, S. \& Ogden, A.D. 1924, On the extent and effects of variety in repetitive work, Medical Research Council, Industrial Fatigue Research Board No. 26. HMSO, London.

Viteles, M. 1932, Industrial Psychology, Norton: New York.

Vroom,V. 1964, Work and Motivation, New York: Wiley

Walker, C.R. \& Guest, R.H. 1952, The Man on the Assembly Line, Harvard University Press: Cambridge, MA.

Wallace, J.E. 1993, Professional and organizational commitment: compatible or incompatible?, Journal of Vocational Behavior, vol. 42, no. 3, 333-349.

Wang, X. 2001, Dimensions and current status of project management culture, Project Management Journal, vol. 32, no. 4, 4-17.

Wang, X. \& Armstrong, A. 2004, An empirical study of PM professionals' commitment to their profession and employing organizations, International Journal of Project Management, vol. 22, no. 5, 377-386.

Weiner, Y. 1982, Commitment in organizations. a normative view, Academy of Management Review, vol. 7, no. 3, 418-428.

Westenholz, A. 2006, Identity work and meaning area-beyond actor/structure and micro/macro distinctions in an empirical analysis of IT workers, American Behavioral Scientist, vol. 49, no. 7, 1015-1029.

\begin{abstract}
About the authors
Ravikiran Dwivedula, MBA (Osmania) PhD (SKEMA Business School) is Director of Research Services and Academic Assessment at Emirates College for Management and Information Technology, Dubai, UAE. His research interests are in the area of work motivation in project-based organisations and projects. He is currently working on a research project (with Christophe Bredillet and Ralf Müller), which investigates the role of work motivation as an antecedent to project management success with organisational and professional commitment as intervening variables. Ravi teaches project management, organisational behavior and human resource management. He has published in PMJ, IJPM and JPPPM and has presented in PMI, IRNOP and EURAM research conferences. He is a reviewer for IJPM, PMJ and JPPPM.
\end{abstract}

Email: dvsravikiran@gmail.com

Christophe Bredillet, PhD, IPMA Level A, FAPM, FIoD, is Director of the Queensland University of Technology Project Management Academy, Australia, and specialises in portfolio, program and project management (P3M) research, consulting and corporate education. From 1992 to 2010, he was Dean of Postgraduate Programs and Studies, and Professor and Head of School of Strategic Management and P3M at ESC Lille. In 2001 he launched a series of International P3M Weeks hosted by ESC Lille, incorporating the first EDEN doctoral seminar in project management in 2008. Christophe's main interests and research activities are in the philosophy of science and practice in P3M, including principles and theories of P3M, dynamics of evolution of the P3M field, bodies of knowledge, standards as conventions and dynamics of standardisation of/by organisations, observation of P3M practices and contexts, and their links with governance, organisational project management and performance at macro, meso and micro levels. He was Executive Editor of the Project Management Journal from 2004 to 2012.

Ralf Müller, MBA (Heriot Watt), DBA (Brunel), PMP, is Professor of Project Management at BI Norwegian Business School, Norway. His principal research interests are in leadership and governance of projects, programs, portfolios and PMOs. He is the author/coauthor of more than 150 publications and has received the 2012 IPMA Research Award (along with Monique Aubry and Brian Hobbs) as well as the Project Management Journal's 2009 Paper of the Year Award. Before joining academia, he spent 30 years in industry. He has consulted with large enterprises and governments in more than 50 different countries and has also held line management positions such as the worldwide director of project management at NCR Teradata. 